\title{
Association of T2 signal intensity of magnetic resonance imaging (MRI) of intracranial meningiomas with their consistency - a review
}

Thayane Araújo Lima ${ }^{1}$, Davi Emanuel de Assis Fonseca ${ }^{1}$, Luan de Sá Pinto Nóbrega Gadelha ${ }^{1}$, Lucas Ravy Pereira Gomes de Souza ${ }^{1}$, Keyvid dos Santos Pereira ${ }^{2}$, Luiz Severo Bem Junior ${ }^{2,3}$

${ }^{1}$ Curso de Medicina da Faculdade de Ciências Médicas de Campina Grande - UNIFACISA, Campina Grande, Paraíba, Brasil.

${ }^{2}$ Departamento de Neurocirurgia do Hospital da Restauração, Recife, Pernambuco, Brasil.

${ }^{3}$ Programa de Pós- graduação de Neurociência, Universidade Federal de Pernambuco, Recife, Pernambuco, Brasil.

\begin{abstract}
Diferents studies have shown a possible association of neuroimaging as a predictor of intratumoral consistency, an important factor during surgery. To identify the correlation between the consistency of intracranial meningiomas and the image of the T2 sequence of magnetic resonance imaging. Using the PRISMA methodology, a search for clinical studies was carried out in the PubMed, Scielo, Medline and Cochrane databases; descriptors: "consistency", "meningioma", "MRI" and "prediction". Twelve articles were found, with seven remaining after the inclusion criteria: articles written in English and published in the last ten years. The T2-weighted magnetic resonance sequence showed highest degree of correlation in the studies discussed, where T2 hyperintensity of soft tumors may be related to a higher water content, while T2 hypointensity for hard tumors may be due to the greater collagen and calcium content. Most studies allow an association to be established between the soft consistency of the tumor and signal hyperintensity in the $\mathrm{T} 2$ sequence of magnetic resonance imaging, with the consistency of the tumor being important, as the surgical difficulty and time depend on it. The hyperintensity of the lesion in T2 was associated with the soft consistency of the tumor, seen during the operation, whereas hypointense meningioma in $\mathrm{T} 2$ is associated with firm consistency.
\end{abstract}

Keywords: meningioma; consistency; MRI; prediction.

\begin{abstract}
Resumo
Estudos diferentes têm demonstrado possível associação da neuroimagem como preditor da consistência intratumoral. Esta revisão tem o objetivo identificar a correlação entre a consistência dos meningiomas intracranianos e a imagem da sequência T2 da ressonância magnética. Utilizando a metodologia PRISMA, foi realizada busca por estudos clínicos nas bases de dados PubMed, Scielo, Medline e Cochrane; utilizando os descritores: "consistency", "meningioma", "MRI" e "prediction". Doze artigos foram encontrados, restando sete após os critérios de inclusão: artigos escritos em inglês e publicados nos últimos dez anos. A sequência de RM ponderada em T2 mostrou o maior grau de correlação nos estudos, onde hiperintensidade em T2 dos tumores moles pode estar relacionada ao maior teor de água, enquanto a hipointensidade para os tumores duros pode ser devido ao teor de colágeno e cálcio. A maioria dos estudos permite estabelecer uma associação entre a consistência mole do tumor e hiperintensidade de sinal na sequência T2 da RM, sendo a consistência do tumor importante, pois ela é um fator influente na dificuldade e no tempo cirúrgico. A hiperintensidade da lesão em T2 foi associada à consistência mole do tumor, constatada no intra-operatório, já a hipointensidade em T2 associa-se a consistência firme.
\end{abstract}

Palavras-chave: meningioma; consistência; ressonância magnética; valor preditivo. 


\section{Introduction}

For intracranial meningiomas, tumor consistency seems also to be of importance in determining the respectability and the surgical outcome, as well as in surgical planning1, estimating the surgical time and the probability of using adjuvant therapy ${ }^{2}$. Some studies claim that there is a probable association between the appearance of these tumors on magnetic resonance imaging (MRI) of the skull and intraoperative observations. They mainly used the $\mathrm{T} 1$ and $\mathrm{T} 2$ sequences to predict the operative findings and to compare the images of fluid attenuated inversion recovery (FLAIR) and the corresponding intraoperative tumor characteristics ${ }^{2,3,5,7,9}$. However, previous studies vary widely in purpose, which refers to the central question of the article and quality, which refers to the method of work, the esteem and quality with which it was developed, and the accuracy of current neuroimaging techniques remains controversial with the theme. Controversies are about the negative correlation, denoted by some studies cited in the articles used as a reference ${ }^{3,4}$

Therefore, the aim of the present study is to correlate the $\mathrm{T} 2$ signal intensity of magnetic resonance imaging (MRI) of intracranial meningiomas with its intraoperative consistency, in order to determine its predictive value to assist in planning and surgical outcome.

\section{Methods}

Study configuration
This study based its methods on the Main Items for Reporting Systematic Reviews and MetaAnalyzes (Prisma). Based on the question "Are there any association between $\mathrm{T} 2$ signal intensity in MRI and meningiomas consistency?", that was established as a guiding principle, the articles selected by the search were submitted to an interpretative analysis.

\section{Search strategy}

On March 26, there was a search in pairs of the articles published in the following databases: PubMed, Scientific Electronic Library Online (SciELO), Medline and Cochrane, and later a complete text review was carried out by all researchers. The articles were selected from their year of publication, specifically from 2010 to 2020 , and without the use of a secondary search from the references of the included articles.

The following keywords were used: meningioma AND consistency AND MRI AND prediction, in the form of the terms MeSH.

\section{Selection criteria}

For this systematic review, studies were selected based on the following criteria: articles written in English and with elapsed time of publication equal to or less than ten years, as reported in figure 1.

Figure 1. Description of the article selection process based on the eligibility criteria.

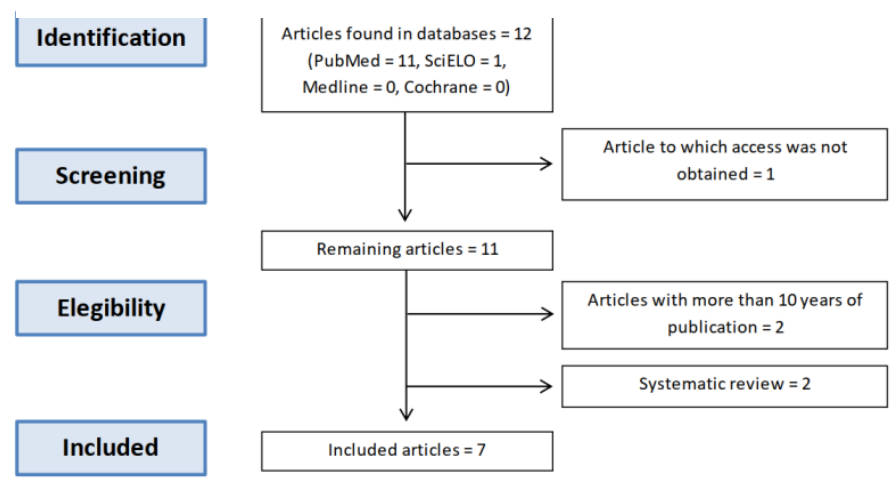


Using the selection criteria, as shown in the table above, studies published in english and in past 10 years, it was possible to select 9 articles that correlated the MRI sequences T1 and T2 to assess the correlation between the consistency of meningiomas in the preoperative period, consequently assisting the surgeon in preoperative planning and counseling. This correlation is established in each article referenced individually and explicitly throughout the text.

\section{Results}

Of the 9 selected studies, under the inclusion criteria: studies in English and published in the last ten years and exclusion criteria: greater than 10 years, which did not answer the question, 7 were case series. The case series totaled 737 patients. In this group, it was possible to perceive a positive and strong correlation regarding the ability to predict tumor consistency with sensitivity, mainly in the T2 sequence, in some studies with up to $90 \%$ sensitivity, and Smith et $a l^{3}$, who analysed one hundred cases in their series, demonstrated an accuracy $89 \%$ and positive predictive value of $84.9 \%$, with $\mathrm{p}<0.05$, showing a useful and effective tool, on which the surgeon can base his decision for surgical planning.

Analyzing the studies included in this review, we will compare them to define whether there is a correlation between the consistency of the meningioma and the T2-weighted MRI sequence, as reported in chart 1 .
Chart 1: Results of the research following the methods described in PRISMA.

\begin{tabular}{|c|c|c|c|}
\hline $\begin{array}{l}\text { Author } \\
\text { and year }\end{array}$ & Methods & $\begin{array}{l}\text { Patients } \\
\text { analysed }\end{array}$ & Conclusion \\
\hline $\begin{array}{l}\text { Smith et } \\
a l, 2016 .\end{array}$ & $\begin{array}{l}\text { Case } \\
\text { series }\end{array}$ & $\begin{array}{l}100 \quad \text { patients. } \\
\text { Positive predictive } \\
\text { value of } 84,9 \% \text {. }\end{array}$ & $\begin{array}{l}\quad \text { Propose a } \\
\text { T2-based } \\
\text { method of } \\
\text { tumor } \\
\text { consistency } \\
\text { prediction with } \\
\text { correlation to } \\
\text { objective } \\
\text { intraoperative } \\
\text { consistency. }\end{array}$ \\
\hline $\begin{array}{l}\text { Watanab } \\
\text { e et al, } \\
2015 \text {. }\end{array}$ & $\begin{array}{l}\text { Case } \\
\text { series }\end{array}$ & $\begin{array}{l}43 \text { patients. } \\
\text { Sensitivity, } \\
\text { specificity and } \\
\text { accuracy were } \\
89 \%, 79 \% \text { and } \\
81 \% \text { for T2W; } \\
89 \%, 76 \% \text { and } \\
79 \% \text { for Flair; } \\
100 \% \text {, } 74 \% \text { and } \\
79 \% \text { for CE- } \\
\text { FIESTA. }\end{array}$ & $\begin{array}{l}\text { Suggest that } \\
\text { a quantitative } \\
\text { assessment } \\
\text { using } \\
\text { conventional } \\
\text { T2W imaging } \\
\text { or FLAIR may } \\
\text { be a simple } \\
\text { and useful } \\
\text { method for } \\
\text { predicting hard } \\
\text { meningiomas. }\end{array}$ \\
\hline $\begin{array}{l}\text { Romani } \\
\text { et at, } \\
2014\end{array}$ & $\begin{array}{l}\text { Case } \\
\text { series }\end{array}$ & 110 patients. & $\begin{array}{l}\text { Fractional } \\
\text { Anisotropy } \\
\text { (FA) value and } \\
\text { Mean } \\
\text { Diffusivity and } \\
\text { FA maps are } \\
\text { useful for } \\
\text { prediction of } \\
\text { meningioma } \\
\text { consistency } \\
\text { and, therefore, } \\
\text { may be } \\
\text { considered in } \\
\text { the preoperative } \\
\text { preoutine MRI } \\
\text { examination of } \\
\text { all patients } \\
\text { with } \\
\text { intracranial } \\
\text { meningiomas. }\end{array}$ \\
\hline $\begin{array}{c}\text { Sitthina } \\
\text { msuwan } \\
\text { et al, } \\
2012 \text {. }\end{array}$ & $\begin{array}{l}\text { Case } \\
\text { series }\end{array}$ & $\begin{array}{l}243 \quad \text { patients. } \\
\text { T2W: } \quad p=0.004 \\
\text { FLAIR: } p=0.045\end{array}$ & $\begin{array}{l}\text { Signal } \\
\text { intensity on } \\
\text { T2WI and } \\
\text { FLAIR image } \\
\text { can be used for } \\
\text { insinuating } \\
\text { meningioma }\end{array}$ \\
\hline
\end{tabular}




\begin{tabular}{|c|c|c|c|}
\hline & & & consistency. \\
\hline $\begin{array}{l}\text { Alyaman } \\
\text { y et al, } \\
2018 .\end{array}$ & $\begin{array}{l}\text { Case } \\
\text { Series }\end{array}$ & $\begin{array}{l}70 \quad \text { patients. } \\
\text { CUSA: } \quad \mathrm{p}=0.046 ; \\
\text { FLAIR: } \\
0.003\end{array}$ & $\begin{array}{l}\text { This study } \\
\text { presents a new } \\
\text { objective } \\
\text { method to } \\
\text { measure the } \\
\text { consistency of } \\
\text { intracranial } \\
\text { meningiomas } \\
\text { based on a } \\
\text { simple } \\
\text { algorithmic } \\
\text { formula. }\end{array}$ \\
\hline $\begin{array}{l}\text { Hoover } \\
\text { et al, } \\
2011 \text {. }\end{array}$ & $\begin{array}{l}\text { Case } \\
\text { Series }\end{array}$ & $\begin{array}{l}101 \text { patients. } \\
\text { Sensitivity: soft } \\
\text { and firm were } \\
90 \% \text { and } 56 \% \text {, } \\
\text { respectively }(95 \% \\
\text { CI }=73-97 \% \text { and } \\
38-73 \% ; \mathrm{p}<0.001)\end{array}$ & $\begin{array}{l}\text { This tool } \\
\text { using T1 and } \\
\text { T2 series } \\
\text { predicts } \\
\text { meningioma } \\
\text { consistency. } \\
\text { Such } \\
\text { knowledge } \\
\text { should assist } \\
\text { the surgeon in } \\
\text { preoperative } \\
\text { planning and } \\
\text { counseling. }\end{array}$ \\
\hline $\begin{array}{c}\text { Karthige } \\
\text { yan et al, } \\
2019 .\end{array}$ & $\begin{array}{l}\text { Case } \\
\text { series }\end{array}$ & 70 patients. & \begin{tabular}{l}
\multicolumn{2}{c}{ FLAIR } \\
hypointensity \\
of \\
meningiomas \\
appears to \\
have \\
significant \\
independent \\
association \\
with the \\
suboptimal \\
operative \\
plane \\
high with \\
specificity.
\end{tabular} \\
\hline
\end{tabular}

Smith $e t a l^{3}$, found from data collected from 100 patients, with tumors between $1.0-9.2 \mathrm{~cm}, 50$ tumors were smooth, 29 intermediate and 21 were firm. The frequency of meningioma consistencies was divided into 3 groups: group $\mathrm{A}$ with tumor cerebellar/ peduncle index 72- weighted imaging intensity (TCTI)> 1.63; group B TCTI index between 1.33-1.63 and group C with TCTI index
<1.27. The comparison between the groups was done with 1-way ANOVA, with each TCTI index having statistical significance $(\mathrm{p}<0.00001)$. He states that the TCTI index correlates with the intraoperative consistency ratings. The author mentions that the consistency of meningioma is a continuum, with overlaps between the soft, intermediate and firm groups. However, the relevance is to differentiate the extreme groups (soft vs firm). Thus, using the ROC curve, they denoted a number for the definition of such consistencies, this optimal value being determined by a TCTI index of 1.41 , with mild tumors greater than or equal to 1.41 and firm tumors less than 1.41. This value has a sensitivity of $81.9 \%$ and $84.9 \%$ specificity.

Chen et al., mentioned in one of the analyzed articles $^{4}$, who, in a prospective study of 54 patients, found a correlation of hyperintensity in T2 with mild tumors, but saw nothing of a correlation in T1; moreover, he says that multiple other studies have shown this same correlation.

According to Watanabe et al..$^{5}$, from a study with 46 patients, in their analysis of correlation between the intensity signal index (SI) in the T2 image, FLAIR and CE-FIESTA showed a significant correlation, with $\mathrm{p}<0.05$. On the other hand, no significant correlation was seen in $\mathrm{T} 1$ and CE-T1WI, with $\mathrm{p}>0.05$.

In the study by Romani et al. ${ }^{6}$, with 110 patients, it was shown that the hyperintense signal in T2WI is not predictive for the consistency of mild meningioma; in its case series, 40 firm and 16 mild tumors showed hyperintensity in T2WI. 
Nevertheless, he states that, at the MD sequence, 39 firm tumors were isointense, and the hypointense signal correlates with statistical significance $(\mathrm{p}=$ 0.008) to firm tumors.

In the study selected for this review by Sitthinamsuwan et al. $^{7}, 243$ patients were analyzed according to the consistency of the tumor and patient variables, such as age, sex, vasogenic edema and tumor characteristics in the T2 sequence of magnetic resonance, with the last variable reaching a $95 \%$ confidence interval $(95 \% \mathrm{CI})$, indicating a statistic with a significant result of $p=0.004$. With that, we evidenced, hypointense meningioma strongly related with hard consistency, while the tumor with higher signal intensity tended to be softer.

In the prospective observational study by Alyamany et al. ${ }^{1}, 54$ patients were included in the total, as out of 70, 16 of them were excluded due to another diagnosis or incomplete data in order to measure the ratio of the ultrasonic cavitron surgical aspirator (CUSA) used in the resection of the tumors and the T2 sequence, with statistical significance of $\mathrm{p}=0.003$.

While Hoover et al. $^{8}$, analyzed 101 patients regarding the use of both $\mathrm{T} 1$ and $\mathrm{T} 2$ in the preoperative period and showed that $\mathrm{T} 2$ hypodensity reached $\mathrm{p}<0.001$ in solid consistency and $\mathrm{T} 2$ hyperdensity $\mathrm{p}=0.05$ and the associated the isodensity or hypodensity of $\mathrm{T} 1$ this statistical significance becomes greater (p <0.01), contributing to the objective of our research.
In this same perspective, Karthigeyan et al. ${ }^{9}$ showed that despite the extent of tumor vascularization, it was significantly correlated with the FLAIR intensity scores, in comparison with the $\mathrm{T} 1$ and $\mathrm{T} 2$ weighted images $(\mathrm{P}<0.05)$ and that the relationship between image T2-meningioma-brain interface and the intraoperative plane was statistically significant $(\mathrm{P}<0.05)$, being able to delimit the tumor well compared to brain tissue.

\section{Discussion}

Intracranial meningiomas account for 20$30 \%$ of all primary non-glial intracranial tumors ${ }^{1}$. Named by Harvey Cushing in 1922, it represents a tumor based on dural originating from arachnoid capillary cells ${ }^{2}$. Epidemiologically, they occur in middle-aged adults and women are affected twice as often as men ${ }^{1}$ with an incidence of approximately 2.3 per 100,000 for benign meningiomas and 0.17 per 100,000 for malignant meningiomas.

Meningiomas are well differentiated, benign and encapsulated lesions that press or that the brain measures that increases ${ }^{1}$. They have a broad spectrum of histologically distinct clinical features and subgroups that are associated with a high risk of recurrence and morbidity, even after thorough inspection. The consistency of the tumor, its vascularization and the surgical plan are important factors $^{2}$.

The pillar of the treatment for meningiomas is the surgical resection that is usually achieved after devascularization the tumor from around the capsule then debunking it from inside using various tools including cavitron ultrasound aspirator 
(CUSA) which is an instrument that combines suction and irrigation with ultrasound.

The correlation between the consistency of the meningioma and the imaging results, especially in MRI, is something that is much discussed today and with little consensus among the literature. Because of its surgical resolution, the consistency of the tumor is extremely important, as well as the size and location. It is already established that surgical difficulty is directly dependent on consistency, as well as increased surgical time in the case of firm consistencies. In addition, surgical time and the likelihood of adjuvant therapy can be estimated.

One of the studies found was a systematic review, in which n: 43 patients were evaluated, it was possible to corroborate the findings present in the other studies, showing that a predictive evaluation is useful to evaluate tumors. Finally, one of the studies, a literature review, went against the other studies, expressing the opinion that there is a need for more grounding in order to have this consistency direction with more reliability.

In the review by Yao et al. ${ }^{2}, 21$ articles were included, of which 16 analyzed the usefulness of T1 and $\mathrm{T} 2$ to predict the consistency of meningioma. All concluded that $\mathrm{T} 1$ alone is not useful for such a prediction, and most noted that, if hyperintense in $\mathrm{T} 2$, the tumors tend to be mild. The probability is almost $100 \%$ that the tumor will be smooth, if it is hyperintense in $\mathrm{T} 2$ and hypointense in $\mathrm{T} 1$ consecutively. However, four authors cited by him did not find such a correlation with T2WI; 03 of these observed only a parallel tendency of hyperintensity and hypointensity in T2WI for smooth and firm tumors, respectively, but without statistical significance.

Through a retrospective study of 54 patients, evidence was found of the relationship between meningioma consistency and T2 weighted image (T2WI MRI) findings, but, on the other hand, they did not do so following $\mathrm{T}_{1} \mathrm{WI}^{7}$. They also say that several other studies show this relationship between T2WI and consistency meningioma. In addition, it is worth mentioning that the hyperintensity on T2WI of soft tumors may be related to higher water content while the lower signal on T2WI for hard tumors might be due to less water and more collagen and calcium content. Based on the evidence above, despite some controversies and still lacking further studies, we found strong and concrete results that lead us to suggest the use of T2WI as a way to predict the consistency of meningioma ${ }^{7}$. This means that the hyperintensity in T2 means a high concentration of water and therefore appears shining in the image, resulting in a soft consistency tumor. Concomitantly, hypointensity in the same sequence shows the low amount of water, showing it to be a solid tumor.

However, in order to avoid researcher bias, we also mention studies that are opposed, that do not demonstrate this relationship and guide further studies on and also those articles that failed to establish a possible relationship between the variables studied, not validating the correlation between meningioma and $\mathrm{T}_{2} \mathrm{WI}^{3}$. 
Finally, it is noteworthy that all studies of quantitative analysis of the review found a correlation of the T2WI sequence with the tumor consistency. The T2-weighted MRI sequence showed the highest degree of correlation in many studies discussed above as also talked about the correlation of consistency in the flair sequence in studies. Similarly, it is suggest and propose the use of both T2WI and the Flair sequence, to predict, in the preoperative period, the consistency of the tumor $1,2,5,7,8$.

\section{Conclusion}

The consistency of meningioma has a predictive value for the surgical planning to be carried out and the respectability and the surgical outcome are determined ${ }^{1}$. It is also possible to estimate the surgical time and the probability that the patient will need adjuvant therapy ${ }^{1}$. The studies that were found are directed to very similar evidence regarding the relevance of the $\mathrm{T} 2$ sequence of MRI for determining the consistency of the meningioma in the preoperative period. The hyperintensity of the lesion in T2 was strongly associated with the soft consistency of the tumor ${ }^{1}$, seen in the intraoperative period, while the $\mathrm{T} 1$ sequence has no predictive value ${ }^{2}$. On the other hand, meningioma that is hypointense in $\mathrm{T} 2$ is associated with firm consistency ${ }^{8}$. From all that has been exposed, the association between the intensity of the meningioma signal in the T2 sequence and the consistency of the lesion is evident.
1. Alyamany M, Alshardan MM, Jamea AA, ElBakry N, Soualmi L, Orz Y (2018) Meningioma Consistency: Correlation Between Magnetic Resonance Imaging Characteristics, Operative Findings, and Histopathological Features. Asian J Neurosurg, 13(2):324-328.

2. Yao A, Pain M, Balchandani P, Shrivastava RK (2018) Can MRI predict meningioma consistency?: a correlation with tumor pathology and systematic review. Neurosurg Rev, 41(3):745-753.

3. Smith KA, Leever JD, Hylton PD, Camarata PJ, Chamoun RB (2017) Meningioma consistency prediction utilizing tumor to cerebellar peduncle intensity on T2-weighted magnetic resonance imaging sequences: TCTI ratio. J Neurosurg, 126(1):242-248.

4. Shiroishi MS, Cen SY, Tamrazi B, D'Amore F, Lerner A, King KS, et al. (2016) Predicting Meningioma Consistency on Preoperative Neuroimaging Studies. Neurosurg Clin N Am, 27(2):145-154.

5. Watanabe K, Kakeda S, Yamamoto J, Ide S, Ohnari $\mathrm{N}$, Nishizawa S, et al (2016) Prediction of hard meningiomas: quantitative evaluate on based on the magnetic resonance signal intensity. Acta Radiol, 57(3):333-340.

6. Romani R, Tang WJ, Mao Y, Wang DJ, Tang HL, Zhu FP, et al. (2014) Diffusion tensor magnetic resonance imaging for predicting the consistency of intracranial meningiomas. Acta Neurochir (Wien), 156(10):1837-1845.

7. Sitthinamsuwan B, Khampalikit I, Nunta-aree S, Srirabheebhat P, Witthiwej T, Nitising A (2012) Predictors of meningioma consistency: A study in 243 consecutive cases. Acta Neurochir (Wien), 154(8):13831389.

8. Hoover JM, Morris JM, Meyer FB (2011) Use of preoperative magnetic resonance imaging $\mathrm{T} 1$ and $\mathrm{T} 2$ sequences to determine intraoperative meningioma consistency. Surg Neurol Int, 2:142.

9. Karthigeyan M, Dhandapani S, Salunke P, Singh P, Radotra BD, Gupta SK (2019) The Predictive Value of Conventional Magnetic Resonance Imaging Sequences on Operative Findings and Histopathology of Intracranial Meningiomas: A Prospective Study. Neurol India, 67(6):1439-1445.

Autor para correspondência Thayane Araújo Lima thayanearaujo1@gmail.com

Recebido: 26 de julho de 2020 Aceito: 11 de dezembro de 2020

\section{References}

